\title{
Immunogenicity Specimen Assessments Data Collection Date Time
}

National Cancer Institute

\section{Source}

National Cancer Institute. Immunogenicity Specimen Assessments Data Collection Date

Time. NCI Thesaurus. Code C117571.

The date and time of immunogenicity specimen assessment data collection. 